\title{
Anemia Among Pregnant Women in the Sidi Bel Abbes Region (West Algeria) : An Epidemiologic Study
}

Demmouche $\mathbf{A}^{*}$, Khelil S and Moulessehoul S

Department of Biology - Djillali Liabes University - Sidi Bel Abbes Algeria

\begin{abstract}
Background and Objectives: Anaemia in pregnancy is a major public health problem in developing countries. It is associated with an increased risk of maternal and perinatal morbidity and mortality. The aim of this present work is to study of prevalence and effect of some socio-biological factors on anemia of pregnancy in a mother-and-child health center $(\mathrm{MCH})$ in area of Sidi Bel Abbes.
\end{abstract}

Subjects and Methods: Across sectional study was conducted during three months (march to may 2010), on a representative sample of 242 pregnant women attending $\mathrm{MCH}$ center in sidi bel abbés region, west of Algeria for the assessment of their hémoglobine level. Most of the women did not have a follow-up at the MHC and they had not taken iron or vitamin supplement during pregnancy. Maternal venous fasting blood samples were collected with EDTA and haemoglobin concentration $(\mathrm{Hb})$; Hematocrit $(\mathrm{Htc})$, Mean cell haemoglobin concentration (MCHC), Mean cell volume (MCV) were determined by an electronic counter.

Results: The overall prevalence of anemia $(\mathrm{H}<11 \mathrm{~g} / \mathrm{dll})$ was found to be $40.08 \%$. Classified in each trimester, the prevalence was $17.3 \%, 23.8 \%$ and $50.0 \%$ in the first, second and third trimester, respectively. According to severity of anemia $36.08 \%$ having mild $49.48 \%$ moderate and $14.43 \%$ severe anemia. The study shows that $46.39 \%$ of the subject had MCV values less than standard value of $75 \mathrm{fl}$ suggesting microcytic anemia.

No correlations were found between the hemoglobin and the maternal obstetric characteristics, in particular not between hemoglobine concentration and parity $(p=0.40)$, betwwen $\mathrm{Hb}$ and number of abortion $(r=0.005$, $p=0.30$ ). Our study shows that age and parity were not a risk factor for anemia.

Conclusions: Iron deficiency is quite frequent during third trimester of pregnancy in our study population. A comprehensive research in our country is needed on how to improve existing iron supplementation programs and the overall health care and nutritional status of women before they enter their reproductive years.

Keywords: Iron; Deficiency; Anaemia; Pregnancy; Supplementation

\section{Introduction}

Iron deficiency anemia is the most common nutritional deficiency in the world; estimates suggest that 2 billion persons worldwide are iron deficient [1]. Because of the increased iron requirements of pregnancy and growth, pregnant women and infants are recognized as the groups most vulnerable to iron deficiency anemia.

Symptomatic iron deficiency during pregnancy has deleterious effects on maternal and perinatal health [2]. Iron deficiency anemia during pregnancy is associated with higher rates of premature birth and low birth weight $[3,4]$ Severe maternal anemia increases the risk of reproduction-related mortality at delivery and during the perinatal period [5]. Iron deficiency in infants may also adversely influence cognitive development [6,7] and may have long-term consequences. Severe iron deficiency anemia in infants has been associated with impaired psychomotor development and developmental delays $>10 \mathrm{y}$ after the treatment of iron deficiency during infancy [8].

The total iron requirements over pregnancy in a $55-\mathrm{kg}$ woman are $\approx 1040 \mathrm{mg}$ [9]. Most of this iron is required during the third trimester, at which time daily iron needs increase from prepregnancy requirements of $\approx 1-1.5 \mathrm{mg} / \mathrm{d}$ to $\leq 6 \mathrm{mg} / \mathrm{d}[5,9]$. The magnitude of this demand is difficult to meet from dietary sources alone, especially in developing countries where the diets are often limited in iron content and bioavailability is generally low or moderate as the result of high intakes of dietary fiber and phytates.

The aim of this present work is to study of prevalence and effect of some socio-biological factors on anemia of pregnancy in a mother-andchild health center $(\mathrm{MCH})$ in area of Sidi Bel Abbes.

\section{Subjects and Methods}

The current study aimed to estimate the prevalence of iron deficiency anemia (IDA) among pregnant women who attend $\mathrm{MCH}$ center in SBA. The study was conducted during the period march - may 2010 and the sample consisted of 242 pregnant women in the age group (18-42) years. No patients had clinical infections or chronic inflammatory diseases.

Blood samples were collected from each pregnant woman and a questionnaire was completed at the time of blood collection, including basic socio-demographic, biological, and reproductive data (age, parity, profession, level of instruction and gestational age), (see appendiece).

Complete blood count $(\mathrm{CBC})$ was conducted for all pregnant women. Maternal venous fasting blood samples were collected with EDTA and haemoglobin concentration $(\mathrm{Hb})$; Hematocrit (Htc), Mean

*Corresponding author: Abbassia Demmouche, Department of Biology, Djillali Liabes University, Sidi Bel Abbes Algeria, E-mail: demmoucheabbassia@yahoo.fr

Received October 31, 2011; Accepted November 19, 2011; Published November 22, 2011

Citation: Demmouche A, Khelil S, Moulessehoul S (2011) Anemia Among Pregnant Women in the Sidi Bel Abbes Region (West Algeria) : An Epidemiologic Study. J Blood Disord Transfus 2:113. doi:10.4172/2155-9864.1000113

Copyright: (C) 2011 Demmouche A, et al. This is an open-access article distributed under the terms of the Creative Commons Attribution License, which permits unrestricted use, distribution, and reproduction in any medium, provided the original author and source are credited. 
Citation: Demmouche A, Khelil S, Moulessehoul S (2011) Anemia Among Pregnant Women in the Sidi Bel Abbes Region (West Algeria) : An Epidemiologic Study. J Blood Disord Transfus 2:113. doi:10.4172/2155-9864.1000113

Page 2 of 6

cell haemoglobin concentration(MCHC), Mean cell volume (MCV) were determined by an electronic counter (ABX micros 60-OT). A hemoglobin value of less than $11.0 \mathrm{~g} / \mathrm{dL}$ was considered to be anemia in pregnancy. The degrees of anemia studied were mild anemia (9.0-10.9 $\mathrm{g} / \mathrm{dL}$ ), moderate anemia (7.0-8.9 g/dL), and severe anemia (less than $7.0 \mathrm{~g} / \mathrm{dL}$ ) [10]. Based on hemoglobin level, all samples with a value less than $10.5 \mathrm{~g} / \mathrm{dL}$ (second trimester) and less than $11 \mathrm{~g} / \mathrm{dL}$ (first and third trimester) were considered to be at risk [11]. Microcytosis was defined as mean corpuscular volume (MCV) lesser than $75 \mathrm{fL}$ and macrocytosis was considered when MCV was greater than $85 \mathrm{fL}$.

Data of the questionnaire and results of blood tests were analyzed using software program stat -vieux (1998). Frequencies and percentages were calculated. chi-square test and ANOVA test were performed to investigate the significance in the association of the different variables and the prevalence of IDA. Correlations were considered significant with the observed significance level (P-value was $<0.05$ ).

\section{Results}

From march 1, 2010 to may31 2010 there were 2892 pregnant women attended the $\mathrm{MCH}$ center in SBA. 242 pregnant women were recruited. The number of pregnant women who first attended the $\mathrm{MCH}$ center during the first, second and third trimester were 22(9.09\%), 13(5.37\%) and $207(85.53 \%)$ cases, respectively (Figure1a).
The mean age was $29.73 \pm 6.74$ years (range 20-46 years) (Figure1b). One hundred six (43.80\%) of the study population were nulliparous and 136 cases (56.19\%) had one child or more (Figure1c). Out of the sample there were 226 (93.38\%) pregnant women without profession and 14 (5.78\%) employee of the public sector. (Figure 1d).

The mean haemoglobin at the first antenatal visit was $(10.9 \pm 1.9 \mathrm{~g} /$ dl), (range 5-14). Using the WHO criterion of haemoglobin less than $11.0 \mathrm{~g} / \mathrm{dl}$ as indicative of anaemia, 97 mothers $(40.08 \%)$ were anaemic (Figure 2), according to the severity was $36.08 \%$ mild, $49.48 \%$ moderate and $14.43 \%$ severe anemia (Figure 3 ). Categorized by trimester, the prevalence of anemia was shown in Table 1. Classified in each trimester, the prevalence was $4.54 \%, 23.07 \%$ and $44.92 \%$ in the first, second and third trimester, respectively.

The mean age of the women was $29 \pm 6.74$ years with a range of 18-42 years. 4.1 percent of them were less than 22 years (Figure $4 a$ ). Fourteen percent of the women low level of education (illiterate, read and write), (Figure $4 \mathrm{~b}$ ). The relationship of anaemia to age of mother, parity, gestational age of pregnancy are shown in Table 2. The age of the mother is no significantly associated with anaemia, with the majority of mothers (38.14\%) who are less than 26 years old being anaemic at the first anatenatal visit $(p=0.13)$. By parity, 45.28 of nullipara, $38.23 \%$ of the primigravida, $33.33 \%$ of the multigravida and $50 \%$ of the grandmultipara were anaemic. Again, parity is shown to be no significantly associated



GESTA TONALA.CE

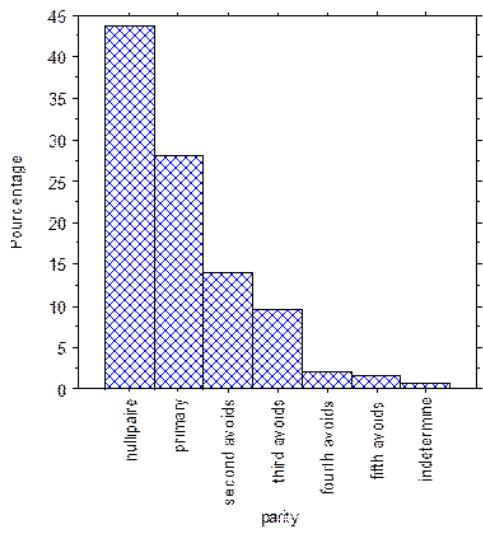

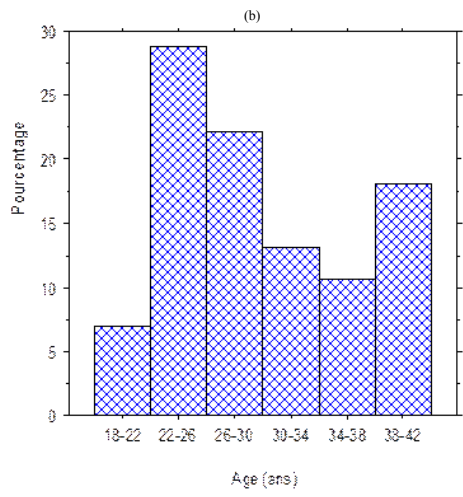

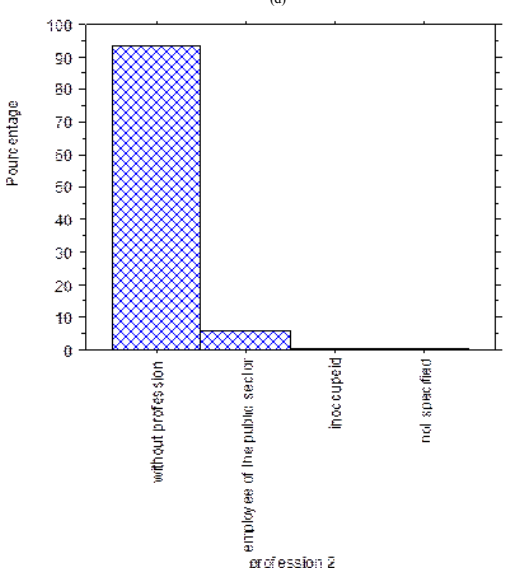

Figure 1: Distribution of the whole sample $(n=242)$ according to gestational age (a), age (b), parity (c), profession (d). 
Citation: Demmouche A, Khelil S, Moulessehoul S (2011) Anemia Among Pregnant Women in the Sidi Bel Abbes Region (West Algeria) : An Epidemiologic Study. J Blood Disord Transfus 2:113. doi:10.4172/2155-9864.1000113

Page 3 of 6

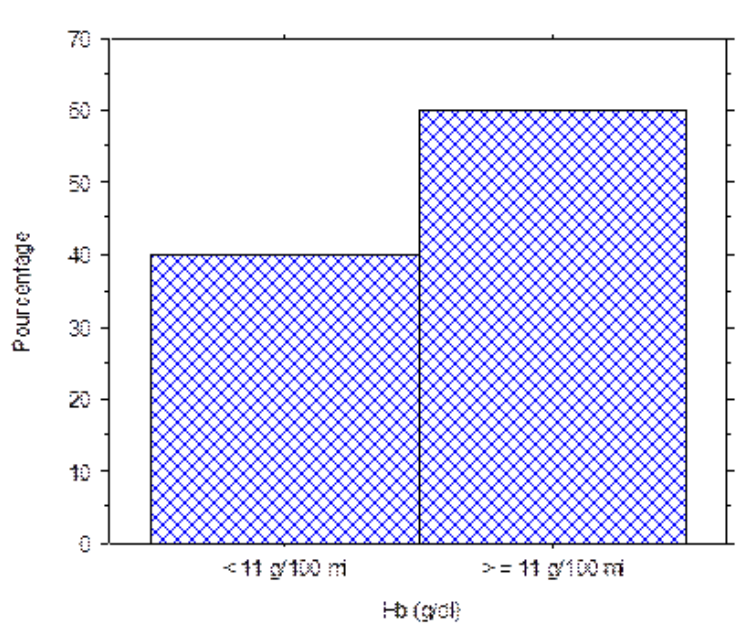

Figure 2: Distribution $(\%)$ of the sample $(\mathrm{n}=242)$ per anemic group $(\mathrm{Hb}<11$ $\mathrm{g} / 100 \mathrm{ml}$ ) and non-anemic group. ( $\mathrm{Hb} \geq 11 \mathrm{~g} / 100 \mathrm{ml}$ ).



Figure 3: Distribution of anemia among pregnant women by severity of anemia.

\begin{tabular}{|l|l|l|l|}
\hline trimester & No anemic women & Anemic women & total \\
\hline first & $21(95.45 \%)$ & $1(4.54 \%)$ & $22(100 \%)$ \\
\hline second & $10(76.92 \%)$ & $3(23.07 \%)$ & $13(100 \%)$ \\
\hline third & $114(55.07 \%)$ & $93(44.92 \%)$ & $207(100 \%)$ \\
\hline total & $145(59.91 \%)$ & $97(40.08 \%)$ & $242(100 \%)$ \\
\hline
\end{tabular}

Table 1: Prevalence of anemia by trimester.

with anaemia $(\mathrm{p}=0.40)$. The gestational age of pregnancy during the first visit also show an association with anaemia in pregnancy. The result shows a significant difference between first trimester / second trimester $(\mathrm{p}=0.48)$, between first trimester / third trimester $(\mathrm{p}=0.001)$ and between second trimester / third trimester $(\mathrm{p}=0.004)$.

The results of the measurements of the various variables in maternal blood during the gestation in women with and without anemia are sumamarized in Table 3.

The mean of $\mathrm{Hb}( \pm \mathrm{SD})$ in the anemic group $(\mathrm{n}=97)$ was $(9 \pm 1.57 \mathrm{~g} /$

\begin{tabular}{|c|c|c|c|c|}
\hline Variable & $\begin{array}{c}<11 \mathrm{~g} / \mathrm{dl} \\
(\%)\end{array}$ & $\begin{array}{c}>11 \mathrm{~g} / \mathrm{dl} \\
(\%)\end{array}$ & $\begin{array}{c}\text { Total } \\
(100 \%)\end{array}$ & $\mathrm{p}$ \\
\hline $\begin{array}{l}\text { Age : } \\
>26 \\
26-34 \\
>34\end{array}$ & $\begin{array}{l}37(42.52) \\
42(48.83) \\
18(26.08)\end{array}$ & $\begin{array}{l}50(57.47) \\
44(51.16) \\
51(7391)\end{array}$ & $\begin{array}{l}87 \\
86 \\
69\end{array}$ & $0.13 \mathrm{NS}$ \\
\hline $\begin{array}{l}\text { Parity : } \\
\text { nullipaire } \\
\text { primary } \\
\text { multiparous } \\
\text { Grand multiparous }\end{array}$ & $\begin{array}{l}48(45.28) \\
26(38.23) \\
22(33.33) \\
1(50)\end{array}$ & $\begin{array}{l}58(54.71) \\
42(61.76) \\
44(66.66) \\
1(50)\end{array}$ & $\begin{array}{l}106 \\
68 \\
66 \\
2\end{array}$ & $0.40 \mathrm{NS}$ \\
\hline $\begin{array}{l}\text { Level of instruction } \\
\text { analphabete } \\
\text {-primary education } \\
\text {-means } \\
\text {-secondary } \\
\text {-academic }\end{array}$ & $\begin{array}{l}14(87.50) \\
15(45.45) \\
31(40.78) \\
23(33.82) \\
14(28.57)\end{array}$ & $\begin{array}{l}2(12.50) \\
18(54.54) \\
45(59.20) \\
45(66.17) \\
35(71.42)\end{array}$ & $\begin{array}{l}16 \\
33 \\
76 \\
68 \\
49\end{array}$ & $040 \quad$ NS \\
\hline $\begin{array}{l}\text { Profession } \\
\text { Without profession } \\
\text {-employee of the } \\
\text { public sector } \\
\text { Inoccupeid } \\
\text { Not specified }\end{array}$ & $\begin{array}{l}91(40.26) \\
6(42.85) \\
0(0.00) \\
0(0.00)\end{array}$ & $\begin{array}{l}135(59.73) \\
8(57.14) \\
1(100) \\
1(100)\end{array}$ & $\begin{array}{l}226 \\
14 \\
01 \\
01\end{array}$ & $0.95 \mathrm{NS}$ \\
\hline $\begin{array}{l}\text { Gestational age } \\
\text { first trimester } \\
\text {-second trimester } \\
\text {-third trimester }\end{array}$ & $\begin{array}{l}1(4.54 \%) \\
3(23.07 \%) \\
93(44.92 \%)\end{array}$ & $\begin{array}{l}21(95.45 \%) \\
10(76.92 \%) \\
114(55.07 \%)\end{array}$ & $\begin{array}{l}22 \\
13 \\
207\end{array}$ & $<0.05 \mathrm{~S}$ \\
\hline
\end{tabular}

Table 2: Factors affecting anaemia in pregnancy among pregnant women.

$\mathrm{dl})$, while in the control group no anemic $(\mathrm{n}=145)$ it was $(12.23 \pm 0.79 \mathrm{~g} /$ $\mathrm{dl}),(\mathrm{p}=0.0001)$.

$46.39 \%$ of the subjects had MCV values less than standard value of $75 \mathrm{fl}$ suggesting microcytic anemia. For the remaining $25.77 \%$ their $\mathrm{MCV}$ were above $>85$ (fl) suggesting megaloblastic anemia (Figure $5 \mathrm{a}$ ). There was a not significant correlation between the Hb level and the MCV level $(r=0.06)$. The MCHC values of about $7.21 \%$ of the subjects were found to be below $<30(\mathrm{~g} / \mathrm{dl})$, for the remaining $92.78 \%$ their MCHC were above $>30(\mathrm{~g} / \mathrm{dl})$ (considered to be normal), (Figure $5 \mathrm{~b}$ ).

The mean of MCHC $( \pm S D)$ in the anemic group $(n=97)$ was $(33.75 \pm 2.79 \mathrm{~g} / 100 \mathrm{ml})$, while in the control group no anemic $(\mathrm{n}=145)$ it was $(33.20 \pm 2.47 \mathrm{~g} / 100 \mathrm{ml}),(\mathrm{p}=0.11)$.

On the other hand, the mean of PCV $(\%),( \pm S D)$ in the anemic group $(\mathrm{n}=97)$ was $(27.00 \pm 5.39 \%)$, while in the control group no anemic $(\mathrm{n}=145)$ it was $(36.94 \pm 3.37 \%),(\mathrm{p}=0.001)$. Finally, the mean of WHITE GLOBULE $( \pm S D)$ in the anemic group $(n=97)$ was $(6.78 \pm 2.12103 /$ $\mathrm{mm} 3)$, while in the control group no anemic $(\mathrm{n}=145)$ it was $(6.74 \pm 1.78$ $103 / \mathrm{mm} 3),(\mathrm{p}=0.88)$.

Table 4 shows relation between maternal age and mean $\mathrm{Hb}$ distribution. The age of the mother is no significantly associated with anaemia. The majority of mothers $(38.14 \%)$ who are less than 26 years old being anaemic at the first anatenatal visit. We found no correlation between the $\mathrm{Hb}$ level and maternal age $(\mathrm{r}=0.17, \mathrm{p}=0,67)$.

Table 5 shows relation between the maternel parity and mean hemoglobine distribution, most were nullipara (49.48\%) while $26.80 \%$ para $1,10.3 \%$ para 2 and the remaining $13.4 \%$ para 3 and above. The mean hemoglobin among the difference parity groups showed no statisticaly significant difference $(\mathrm{p}=0.40)$.

The results shows that the profession and mean hemoglobin distribution, most were without profession (93.81\%). The mean hemoglobine among the difference groups showed no statisticaly significant difference $(\mathrm{p}=0.32)$, (Table 6). 
Citation: Demmouche A, Khelil S, Moulessehoul S (2011) Anemia Among Pregnant Women in the Sidi Bel Abbes Region (West Algeria) : An Epidemiologic Study. J Blood Disord Transfus 2:113. doi:10.4172/2155-9864.1000113

(a)

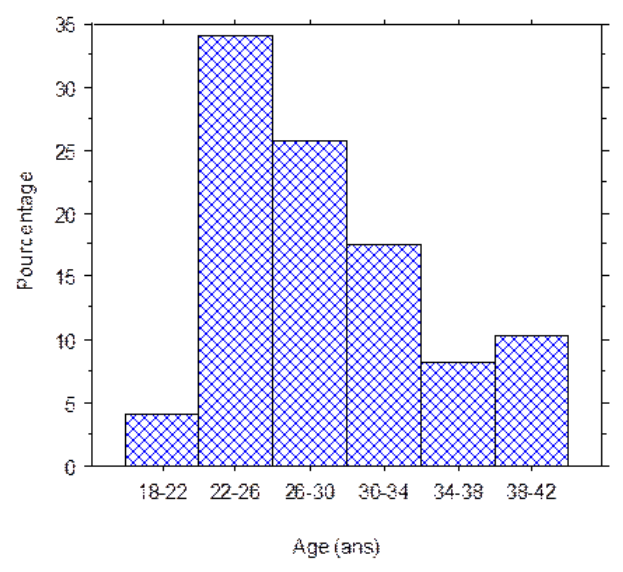

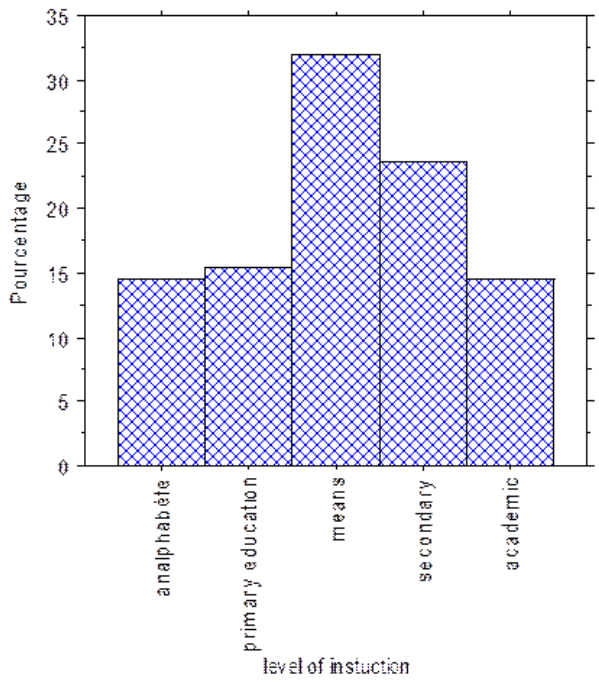

Figure 4: Distribution of the anemic women ( $n=97)$ according to age (a) and level of instruction (b).

(a)

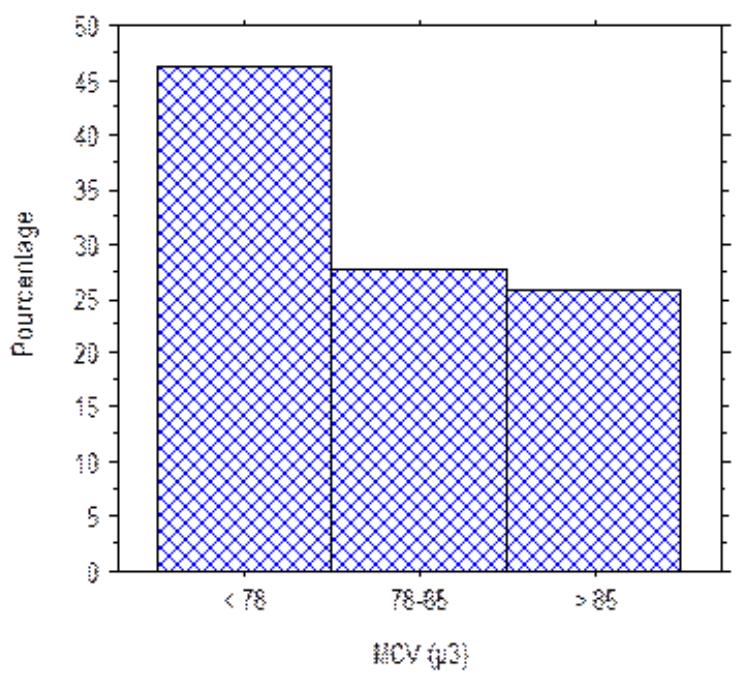

(b)



Figure 5: Distribution of the whole sample ( $n=97)$ according to MCV (fl) level (a) and MCHC(g/dl) level (b).

The level of instruction and mean hémoglobine distribution are summarized in (Table 7). The mean hemoglobine among the difference level of instruction groups showed statisticaly significant difference $(\mathrm{p}=0.009)$. In particular between Analphabete / means $(\mathrm{p}=0.02)$, Analphabete / academic $(p=0.003)$, primary education / means $(p=0.02)$ and primary education / academic $(\mathrm{p}=0.004)$. However, we found a correlation between $\mathrm{Hb}$ and $\mathrm{Htc}(\mathrm{r}=0.98)$, (Figure 6).

\section{Discussion}

Anemia associated with pregnancy is a public health problem. The world health organisation report gives anemia prevalence picture at global level at 55.9\% among the expectant mothers [12] .

The prevalence of anemia in pregrancy in these study, $40.08 \%$ is similar than the $37-56 \%$ given bu the world health organisation [13]. Using the critirion of hemoglobin concentration $<11 \mathrm{~g} / \mathrm{dl}$ to define anemia. However, given the fact that is now generally accepted that the maternal iron status can not be assessed simply from hemoglobine concentration [14], care needs to be taken in interpreting this finding. Hemoglobin concentration taken along with mean corpuscular volume is a better indication for anemia or lack of it [14].

The mean hemoglobin concentration in this study of $10.9 \pm 1.9 \mathrm{~g} /$ $\mathrm{dl}$ is similar to findings in other studies though the exact figures are not usually available for developing countries, the published rates are applicable to selected urban group of women $[15,16]$.

Most of the anemic women $(49.48 \%)$ in this study were of the 
Citation: Demmouche A, Khelil S, Moulessehoul S (2011) Anemia Among Pregnant Women in the Sidi Bel Abbes Region (West Algeria) : An Epidemiologic Study. J Blood Disord Transfus 2:113. doi:10.4172/2155-9864.1000113

\begin{tabular}{|c|c|c|c|c|c|}
\hline & $\begin{array}{c}\mathrm{Hb}(\mathrm{g} / \mathrm{dl}) \\
\text { Mean } \pm \text { SD }\end{array}$ & $\begin{array}{c}\mathrm{PCV}(\%) \\
\text { Mean } \pm \text { SD }\end{array}$ & $\begin{array}{c}\text { MCV(fl) } \\
\text { Mean } \pm \text { SD }\end{array}$ & $\begin{array}{c}\text { MCHC } \\
(\mathrm{g} / 100 \mathrm{ml}) \\
\text { Mean } \pm \text { SD }\end{array}$ & $\begin{array}{c}\text { White } \\
\text { globule } \\
10^{3} / \mathrm{mm}^{3} \\
\text { Mean } \pm \text { SD }\end{array}$ \\
\hline $\begin{array}{c}\text { Anemic } \\
\text { women } \\
(\mathrm{n}=97)\end{array}$ & $9.00 \pm 1.57$ & $27.00 \pm 5.39$ & $75.70 \pm 10.48$ & $33.75 \pm 2.79$ & $6.78 \pm 2.12$ \\
\hline $\begin{array}{c}\text { No anemic } \\
\text { women }(\mathrm{n}= \\
145)\end{array}$ & $12.23 \pm 0.78$ & $36.94 \pm 3.37$ & $84.65 \pm 4.24$ & $33.20 \pm 2.47$ & $6.74 \pm 1.78$ \\
\hline $\begin{array}{c}\text { WHO } \\
\text { VALUE }\end{array}$ & $>11$ & $>33$ & $75-85$ & $30-35$ & $4-10$ \\
\hline \multicolumn{1}{|c|}{} & 0.13 & 0.001 & 0.001 & 0.11 & 0.88 \\
\hline
\end{tabular}

S: significatif $(p<0.05)$

NS: no significatif $(p>0.05)$

Tables 3: Parameters hematologic statute (average \pm SD, manpower) of the whole of the sample and comparison enters the anemic group and non anemic group.

\begin{tabular}{|c|c|c|c|}
\hline Age & Number & Percentage $\%$ & Mean $\mathrm{Hb} \pm \mathrm{SD}$ \\
\hline $18-22$ & 4 & 4.12 & $8.64 \pm 2.29$ \\
\hline $22-26$ & 33 & 34.02 & $8.91 \pm 1.68$ \\
\hline $26-30$ & 25 & 25.77 & $8.69 \pm 1.57$ \\
\hline $30-34$ & 17 & 17.52 & $9.35 \pm 1.28$ \\
\hline $34-38$ & 8 & 8.24 & $9.51 \pm 1.34$ \\
\hline $38-42$ & 10 & 10.30 & $9.24 \pm 1.61$ \\
\hline total & 97 & 100 & $9.05 \pm 1.62$ \\
\hline
\end{tabular}

Table 4: Relation between maternal age and mean $\mathrm{Hb}$.

\begin{tabular}{|c|c|c|c|}
\hline parity & Number & Percentage $\%$ & Mean $\mathrm{Hb} \pm \mathrm{SD}$ \\
\hline 0 & 48 & 49.48 & $8.85 \pm 1.71$ \\
\hline 1 & 26 & 26.80 & $9.08 \pm 1.31$ \\
\hline 2 & 10 & 10.3 & $9.56 \pm 1.45$ \\
\hline $3-5$ & 12 & 12.37 & $9.83 \pm 0.48$ \\
\hline 6 §above & 1 & 1.03 & $6.25 \pm 0.00$ \\
\hline
\end{tabular}

Table 5: Relation between parity and mean $\mathrm{Hb}$.

\begin{tabular}{|c|c|c|c|}
\hline profession & Number & Percentage $\%$ & mean $\mathrm{Hb} \pm \mathrm{SD}$ \\
\hline Without profession & 91 & 93.81 & $8.96 \pm 1.57$ \\
\hline $\begin{array}{c}\text { Employee of the } \\
\text { public sector }\end{array}$ & 6 & 6.18 & $9.62 \pm 1.42$ \\
\hline total & 97 & 100 & $9.29 \pm 1.49$ \\
\hline
\end{tabular}

Table 6: Relation between profession and mean $\mathrm{Hb}$

\begin{tabular}{|c|c|c|c|}
\hline Level of instruction & Number & Percentage $\%$ & Mean $\mathrm{Hb} \pm \mathrm{SD}$ \\
\hline analphabéte & 14 & 14.43 & $8.19 \pm 1.52$ \\
\hline Primary education & 15 & 15.46 & $8.26 \pm 1.51$ \\
\hline means & 31 & 31.95 & $9.33 \pm 1.50$ \\
\hline secondary & 23 & 23.71 & $9.00 \pm 1.71$ \\
\hline academic & 14 & 14.43 & $9.89 \pm 0.85$ \\
\hline total & 97 & 100 & $8.93 \pm 1.41$ \\
\hline
\end{tabular}

Table 7 : Relation between level of instruction and mean $\mathrm{Hb}$

moderate variety, $36.08 \%$ were mild anemic and $14.43 \%$ were severly anemic. Compared with other recent studies from southh eastern Nigeria and Ibadan $[17,18]$, Western Nigeria , no cases of sever anemia was noted [19], unlike in Shagamu, western nigeria were $0.7 \%$ of the anemic pregnant women were severly anemic [20]. Also in southern malawi, 3.6\% of anemic pregnant women were of the sever variety $(\mathrm{Hb}<7 \mathrm{~g} / \mathrm{dl})$.

In our study, $46.39 \%$ had MCV values less than standard value of



Figure 6: Correlation between PCV and $\mathrm{Hb}$.

$75 \mathrm{fl}$ suggesting microcytic anemia. Also, the determination of PCV has shown that about $55 \%$ of the subjects had hypochromic type of anemia. This suggests that the cells were lacking iron. This observation is similar to that made by flemming (1989) in Ndola [21], Zambia and Nigeria where about more than $50 \%$ of the subjects had PCV values less than $33 \%[22]$.

As a result of IDA, it is considered that more than half a billion people of the world have deleterious effects [23]. So, Ogbeide et al [24] recommend a regular review of factors which may contribute to prevent the maternal anemia. However, there is still controversy surrounding the impact of the anemia on outcome of pregnancy, at least in developed countries [25,26]. Nevertheless, Scholl et al $[27,28]$ point out that the relationship between inadequate iron intake and increased likelihood of preterm delivery is kept during the third trimester.

Independently of its impact on fetal health, maternal anemia increases the risk of maternal morbidity [29]. Therefore, it is very important to prevent and to treat maternal anemia. Looker et al [30] report 2\% to 5\% of American teenagers with iron deficiency. In a recent study in Brasil, in São Paulo, the prevalence of anemia in pregnant adolescents was $14.2 \%$, nevertheless the frequency of ID was high (48.4\%)[31]. Regarding Looker's results, our study showed a prevalence four times higher and in comparison with Brasil it was twice as high $[30,32]$.

Although the pregnant adolescent was not our central objective, we should mention that the adolescent didn't have a statistically significant association with anemia in general or any one of its types. Similar results are shown in a review and Meta-analysis by Scholl et al [32]. Contrary to Beard that points out that adolescence is a risk factor for maternal anemia [33]. We considered that the rational approach to IDA in this group is not different to the other pregnant woman. The evaluation of anemia during pregnancy is not very different than that of any anemic adult.

Age and parity were not a risk factor for anemia in our study. 
Mahfouz et al [34,35] found that saudi teenage pregnant femals were not a higher risk of anemia than older women if good prenatal care was provided. Unlike some studies we did not observe any variation in anemia by parity.

Advancing gestational age significantly increased the risk of anemia, wich is similar to the finding of other studies but varient with a related study in zimbabwe $[34,36,37]$, which found that gestational age were not significant predictors of hemoglobin concentration [38].

Compared to the first trimester, a lower hemoglobine level in the second and third trimester is partly artifactual and is due to a physiological expantion of maternal plasma volume, making it more or less difficult to separate out women who are truly anemic.

To prevent depletion of iron stores during pregnancy we favor prophylactic iron supplementation in all pregnant women from the begenning of the second trimester until delivery.

\section{Conclusion}

The current study aimed to estimate the prevalence of iron deficiency anemia (IDA) among pregnant women who attend $\mathrm{MCH}$ center in SBA.

Anemia is extremely common in pregnant women. It is particularly high in areas of the world that also have high rates of low birth weight (LBW). The results of the present systematic review suggest that prevalence of anemia during pregnancy in SBA is similar than what has been reported by WHO; however, there seems to be the need to implement programmes to reach an reach an ideal state of the disease.

The prevalence of anaemia is all the more high as the age of the pregnancy is more advanced. Therefore, it appears essential to consider a program of systematic iron supplementation from the beginnig the second trimester of the pregnancy.

Hemoglobine concentration is done routinaly for all pregnant women attending ante-natal care clinics in the region. The women are offered iron supplementation routinely. The major obstacle to iron supplementation is compliance with treatment. This is often due to its side effects and women lack awareness that they have a real need for iron during pregnancy. Giving tablets is not enough to ensure success. Women must be convinced of the importance of iron for their health and the health of the baby.

Health education programs MCH center in SBA should be revised to stress the importance of balanced diet and the benifits to be gained from compliance with iron medication. Emphasis should be given to sufficient spacing between subsequent pregnancy.

In conclusion, although the adopted strategy concerning primary health care seems to be well planned and based on international recommendations, it seems to have no noticeable effect on the improvement of the prevalence of IDA and there is a great need for further health education promotional programs in this respect.

\section{References}

1. WHO, Maternal Health and Safe Motherhood Division of Family Health. (1991) The prevalence of nutritional anaemia in women. Geneva.

2. Allen LH (2000) Anemia and iron deficiency: effects on pregnancy outcome. Am J Clin Nutr $71: 1280 S-1284 S$

3. Scholl TO, Reilly T (2000) Anemia, iron and pregnancy outcome. J Nutr 130: 443S-447S.

4. Garn SM, Ridella SA, Petzold AS, Falkner F (1981) Maternal hematologic levels and pregnancy outcomes. Semin Perinatol 5:155-162.
5. Viteri FE (1994) The consequences of iron deficiency and anemia in pregnancy Nutrient regulation during pregnancy, lactation and growth. Plenum Press, New York.

6. Lozoff B, Wolf AW, Jimenez E (1996) Iron-deficiency anemia and infant development: effects of extended oral iron therapy. J Pediatr 129: 382-389.

7. Walter T (1994) Effect of iron-deficiency anaemia on cognitive skills in infancy and childhood. Baillieres Clin Haematol 7: 815-827.

8. Lozoff B, Jimenez E, Hagen J, Mollen E, Wolf AW (2000) Poorer behavioral and developmental outcome more than 10 years after treatment for iron deficiency in infancy. Pediatrics [serial online] 105: E51.

9. Bothwell TH (2000) Iron requirements in pregnancy and strategies to meet them. Am J Clin Nutr 72: 257S-264S.

10. World Health Organisation. (1972) Nutritional anemias.WHO Tech Rep

11. Centers for Disease Control and Prevention: CDC criteria for anemia in children and Child bearing aged women. (1989) MMWR 38: 404.

12. WHO Report. (1992) Report of working group on anemia

13. World Health organisation. (1992)The prevalence of anemia in women Tabulation of available Information. Geneva WHO.

14. Steer PJ (2000) Maternal hemoglobin concentration and birth weight. AmJ ClinNutr 71: 1285S-1287S

15. Akanmu AS, Akinsete I, Njoku OS, Abudu OO (1999) Defining anemia in pregrancy in lagos, Nigeria. Nigpostgrad Med J 6 : 22-26.

16. Van Den Broek N (1998) Anemia in pregnancy in developing countries. Br Obstet Gynaecol 105: 385-390.

17. Aluka C, Amadi AN, Kmanu Cl, Feyi Waboso PA (2001) Anemia in pregrancy in Abia Stat University Teaching Hospital Aba. J Med Invest Pract (JOMIP) 2: 58-61.

18. Adinma JIB, Ikechebelu JI, Onyejimbe UN, Amilo G, Adinma E (2002) Influence of antenatal care on the haematocrit value of pregnant Nigerian Igbo women. Trop J Obstet Gynaecol 19: 68-70.

19. Aimaku CO, Olayemi O (2003) Maternal haematocrit and pregnancy outcome in Nigerian women. West African J Med 22: 18-21.

20. Lamina MA, Sorunmu TO (2003) Prevalence of anaemia in pregnant women attending the antenatal clinic in a Nigerian university teaching hospital. Nigerian Med Pract 44: 39-42.

21. Andrews NC (1999) Disorders of iron metabolism. N Engl J Med 341: 19861995.

22. Fleming AF (1989) The aetiologie of severe anemia in pregnancy in Zambia Ann Trop Med Parasitol 83: 37-49.

23. Dallman PR (1989) : Iron deficiency : does it matter? J Int Med 226: 367-372

24. Ogbeide O, Wagbatsoma V, Orhue A (1994) Anaemia in Pregnancy. E Afr Med J 71: 671-673

25. Mahomed K (1998) Routine iron supplementation during pregnancy [Cochrane review]. Pregnancy and childbirth module of the Cochrane Database of Systematic Reviews. The Cochrane Library, Oxford.

26. Kramer MS (1998) Maternal nutrition, pregnancy outcome and public health policy. CMAJ 159: 663-665

27. Scholl TO, Hediger ML (1994) Anemia and iron-deficiency anemia: compilation of data on pregnancy outcome. Am J Clin Nutr 59: 492S-501S.

28. Scholl TO, Hediger ML, Fisher RL, Shearer JW (1992) Anemia vs iron deficiency: increased risk of preterm delivery in a prospective study. Am J Clin Nutr 55: 985 988

29. Oppenheimer S, Hendrickse R (1983) The clinical effects of iron deficiency and iron supplementation. Nutrition Abstracts and Reviews in Clinical Nutrition. Serie A 53: $585-598$

30. Looker AC, Dallman PR, Carroll MD, Gunter EW, Johnson CL (1997) Prevalence of iron deficiency in the United States. JAMA 277: 973-976.

31. Fujimori E, Oliveira IMV, Nuñez de Cassana LM, Szarfarc SC (1999) Estado 
Citation: Demmouche A, Khelil S, Moulessehoul S (2011) Anemia Among Pregnant Women in the Sidi Bel Abbes Region (West Algeria) : An Epidemiologic Study. J Blood Disord Transfus 2:113. doi:10.4172/2155-9864.1000113

Nutricional del hierro de gestantes adolescentes, São Paulo, Brasil. Arch Latinoamer Nutr 49: 8-12

32. Scholl TO, Hediger ML, Belsky DH (1994) Prenatal Care and Maternal Health During Adolescent Pregnancy: A review and Meta-analysis. J Adolesc Health 15: $444-456$

33. Beard L (1994) Iron Deficiency assessment during pregnancy and its importance in pregnant adolescents. Am J Clin Nutr 59: 502S-508S.

34. Mahfouz AA, El-Said MM, Alakija W, Badawi IA, Al-Erian RA, et al. (1997) Anemia among pregnant women in the asir region, Saudi Arabia ; an epidimiological study. Southeast Asian J Trop Med Public Health 25: 84-87.
35. Afifl M (2003) Anemia in pregnancy at South Sharqiya health centers,Oman. J Egypt Public Health Assoc 78: 39-54.

36. Suega K, Dharmayuda TG, Sutarga IM, Bakta IM (2002) Iron deficiency anemia in pregnant women in Bali, Indonesia : a profile of risk factors and epidemiology. Southeast Asian J Trop Med Public Health 33: 604-607.

37. Massot C, Vanderpas J (2003) A survey of iron deficiency anemia during pregrancy in Belgium : analysis of routine hospital laboratory data in Mons. Acta Clin Belg 58: 169-177.

38. Friis H, Gomo E, Kaestel P, Nyazema N, Krarup H (2001) HIV and other predictors of serum folate, serum ferritin, and hemoglobin in pregnancy : a cross sectional study in Zimbabwe. Am J C lin Nutr 73: 1066-1073. 